\section{AJ $\mathrm{H}$ \\ ISSN 0973-4767}

Article history : Received : 28.02.2020 Revised : 04.05.2020 Accepted : 21.05.2020
Members of the Research Forum Associated Authors:

${ }^{1}$ Department of Vegetable Science, University College of Agriculture, Guru Kashi University, Talwandi Sabo, Bathinda (Punjab) India

Author for correspondence : Navdeep Singh

Department of Vegetable Science, University College of Agriculture, Guru Kashi University, Talwandi Sabo, Bathinda (Punjab) India Email : navdeep.brar50@gmail.com

\section{Evaluation of bottle gourd [Lagenaria siceraria (Molina) Standl.] genotypes for various growth and yield characters}

\author{
Navdeep Singh and Harpal Singh ${ }^{1}$
}

\begin{abstract}
The present investigation "Evaluation of bottle gourd genotypes [Lagenaria siceraria (Mol.) Standl.] for various growth and yield characters" was carried out in experimental area of research farm of Guru Kashi University, Talwandi Sabo (Bathinda) during Kharif season 2017-2018. The experiment was laid out in Randomized Block Design (RBD) comprising of 11 genotype lines with three replications of each treatment. Sowing was done in April, 2017. The observation were recorded on three randomly selected plants with respect to characters viz., number of primary branches per vine, plant height (Vine length), days to first flower, node to first flower, fruit length $(\mathrm{cm})$, fruit girth $(\mathrm{cm})$, fruit rind thickness $(\mathrm{mm})$, fruit flesh thickness $(\mathrm{mm})$, total soluble solids (TSS ${ }^{\circ}$ Brix), average, fruit weight (g), number of fruits per plant and fruit yield per plant $(\mathrm{kg})$. From observations maximum number of branches 11.5 and maximum vine length $745.5 \mathrm{~cm}$ was recorded in SEL-6.Minimum days to first flowering (41 days) was recorded in SEL-9. Minimum node to first flowering 7.2, maximum breadth $16 \mathrm{~cm}$ was recorded in SEL-1 and maximum fruit length $35.5 \mathrm{~cm}$ was in SEL-5. Minimum flesh thickness $68.0 \mathrm{~mm}$ and maximum TSS $4.8^{\circ} \mathrm{B}$ was recorded in Punjab Bahar (check variety). Maximum average fruit weight 1458.1 $\mathrm{g}$ was recorded in SEL-3. Maximum number of fruits per vine 13.9 and yield per vine $14.8 \mathrm{~kg}$ were recorded in SEL-8.
\end{abstract}

KEY WORDS : Bottle gourd, Genotypes, Variability

HOW TO CITE THIS ARTICLE : Singh, Navdeep and Singh, Harpal (2020). Evaluation of bottle gourd [Lagenaria siceraria (Molina) Standl.] genotypes for various growth and yield characters. Asian J. Hort., 15(1) : 4-6, DOI : 10.15740/HAS/TAJH/15.1/4-6. Copyright@ 2020 : Hind Agri -Horticultural Society 